J. Lake Sci.(湖泊科学) , 2019, 31(4): 919-929

DOI 10. 18307/2019. 0421

(c) 2019 by Journal of Lake Sciences

\title{
2010－2017 年太湖总磷浓度变化趋势分析及成因探讨”
}

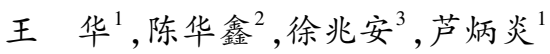 \\ ( 1 : 太湖流域水资源保护局, 上海 200434) \\ (2:太湖流域管理局水利发展研究中心,上海 200434) \\ (3: 太湖流域水文水资源监测中心, 无锡 214024)
}

\begin{abstract}
摘 要: 近年来, 太湖流域各省市政府加大治理力度,流域水体水质取得明显好转,氨氮浓度和总氮浓度呈大幅度下降趋 势, 然而太湖水体总磷浓度呈上升趋势. 为探讨太湖总磷浓度升高的原因, 采用太湖流域管理局 2010 年以来的水质水量 实测数据、遥感监测数据等, 分别从太湖人湖河流污染负荷量、水生植被和蓝藻与总磷浓度的关系 3 个方面进行相关性分 析. 结果表明, 入湖河流总磷浓度高于太湖水体总磷浓度, 且磷不易出湖, 逐年总磷净入湖量持续累积与太湖总磷浓度有 明显的正相关性, 人湖污染负荷量大是太湖总磷浓度居高不下的根本原因; 水生植被可吸收湖泊沉积物中的营养盐, 并 抑制底泥再悬浮从而降低内源性营养盐的释放, 东太湖水生植被的大量减少, 一方面减少了沉水植物对磷元素的吸收, 另一方面增加了风浪对底泥的扰动再悬浮, 造成磷元素释放, 是造成湖水总磷浓度升高的重要因素; 近年来太湖蓝藻密 度呈上升趋势, 受其影响, 总磷浓度也有上升, 蓝藻水华加快湖体磷循环, 藻类密度增加也是太湖总磷浓度升高的影响因 素之一.
\end{abstract}

关键词: 太湖;总磷;污染负荷;底泥释放;水生植被;蓝藻

\section{Variation trend of total phosphorus and its controlling factors in Lake Taihu, 2010-2017}

\author{
WANG Hua ${ }^{1}$, CHEN Huaxin ${ }^{2}$, XU Zhao'an ${ }^{3} \&$ LU Bingyan ${ }^{1}$ \\ (1: Taihu Basin Water Resource Protecition Bureau, Shanghai 200434, P.R.China) \\ (2: Water Conservancy Development Reseach Center of Taihu Basin Authority, Shanghai 200434, P.R. China) \\ (3: Monitoring Bureau of Hydrology and Water Resources, Taihu Basin Authority, Wuxi 214024, P.R.China)
}

Abstract: In recent years, the water quality of water bodies in Lake Taihu Basin has improved significantly because that all provinces and municipalities in the basin have intensified their efforts in pollution governance. In Lake Taihu, the concentration of ammonia nitrogen and total nitrogen showed a significant downward trend, while a upward trend for the concentration of total phosphorus ( TP). To explore the reasons for such TP increase, this paper used the measured data and remote sensing data between 2010 to 2017 from Lake Taihu Basin Authority of Ministry of Water Resources. We analyzed the correlation between the pollution load of inflow river, aquatic vegetation and cyanobacteria and the TP. The results showed that the TP in the inflow rivers was higher than those in the Lake Taihu, and TP was not easy to remove from the lake. There was a significant positive correlation between the continuous accumulation of TP loading and the epilimnetic TP in Lake Taihu. It is concluded that the basic factor of the high TP concentration is the large amount of phosphorus loading into the lake. Aquatic vegetation can absorb nutrients from lake sediments and inhibit the resuspension of sediment so as to reduce the release of endogenous nutrients. The substantial decrease of aquatic vegetation led to the increase of TP concentration in East Lake Taihu. Recently the abundance of blue-green algae in Lake Taihu showed an increasing trend. Under such circumstance, the monitoring TP also increased.

Keywords: Lake Taihu; total phosphorus; pollution loading; sediment release; aquatic plants; blue-green algae

太湖地处长江三角洲南缘, 是大型浅水湖泊, 水域面积 $2338 \mathrm{~km}^{2}$, 平均水深 $1.9 \mathrm{~m}$, 最大水深约 $3.4 \mathrm{~m}$, 是 太湖流域水生态系统的中枢. 2007 年 5 月底发生的太湖蓝藻暴发以及由此导致的无锡市供水危机, 严重影

* 江苏省科技计划项目 (BE2018737) 资助. 2018-09-27 收稿; 2019-01-31 收修改稿. 王华(1968 ), 女, 本科, 高级 工程师; E-mail: huawang163.com@163.com. 
响了当地近百万群众的正常生活,引起社会广泛关注, 2008 年 5 月国务院批复实施《太湖流域水环境综合治 理方案》.

对于湖泊富营养化和蓝藻水华暴发, 研究氮、磷等营养盐浓度的变化, 已经是国内诸多专家主要研究方 向. 戴秀丽等 ${ }^{[1]}$ 分析了太湖水体氮、磷浓度 1985-2015 年的演变趋势, 全太湖水体氮、磷指标总体呈先恶 化、后好转的波动变化趋势, 而总磷浓度则没有明显的季节性变化规律. 吴攀等 ${ }^{[2]}$ 探索太湖流域水环境质量 随经济发展的变化趋势, 结果表明人湖总磷负荷与太湖上游流域废水排放总量呈显著正相关. 朱伟等 ${ }^{[3]}$ 研 究太湖典型湖区梅梁湾和贡湖湾 2010-2017 年水质变化时, 发现这两个湖区总磷浓度在 2014 年前也是在 波动中呈现下降的趋势, 但在 2015 和 2016 年有所回升. 朱广伟等 ${ }^{[4]}$ 对北部太湖 14 个监测点 2005-2017 年 的营养盐和叶绿素 a 浓度逐月监测数据分析, 发现 2015 年以来, 北部太湖水体叶绿素 a 浓度呈显著增高特 征, 且近年来总磷浓度有升高趋势, 溶解性总磷浓度也无明显下降趋势. 大量相关研究 ${ }^{[5-12]}$ 表明, 氮、磷指标 是造成太湖湖体富营养化的关键因子.

近 10 年来, 太湖流域各省市政府加大治理力度,流域河流水体水质取得明显好转. 2010-2017 年, 太湖 水体氨氮浓度和总氮浓度呈大幅度下降趋势, 降幅分别为 $52.2 \%$ 和 $35.5 \%$, 但太湖水体总磷浓度却呈上升趋 势, 增幅为 $16.9 \%$. 本文通过分析近年来太湖人湖污染负荷、水生植被和蓝藻 3 方面变化, 探讨近年来造成磷 浓度升高的影响因素, 这些分析对于正确理解太湖磷浓度现状, 更加科学地制定治理措施有着重要的参考 价值.

\section{1 材料与方法}

\section{1 监测点布设}

太湖共布设 33 个监测点, 分设在 9 个湖区, 分别在梅梁湖 5 个、竺山湖 2 个、贡湖 4 个、东太湖 3 个、湖 心区 6 个、西部沿岸区 2 个、东部沿岸区 4 个、南部沿岸区 5 个和五里湖 2 个 (图 1 和表 1 ). 监测点位覆盖了 太湖全部水域,监测频次为每年 12 次,每月上旬监测 1 次.

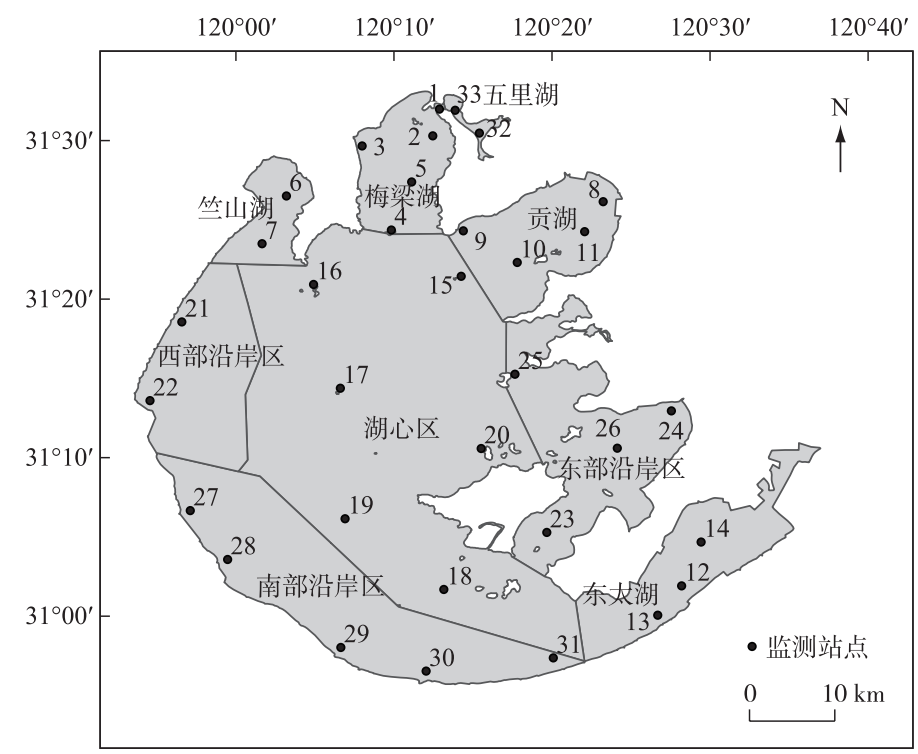

图 1 太湖各分区及监测点分布

Fig.1 Distribution of lake regions and monitoring sites of Lake Taihu 
表 1 太湖水质监测站点概况

Tab.1 List of water quality monitoring sites in Lake Taihu

\begin{tabular}{|c|c|c|c|c|c|c|c|c|}
\hline 序号 & $\begin{array}{c}\text { 湖区 } \\
\left(\text { 面积 } / \mathrm{km}^{2}\right)\end{array}$ & 监测点 & 序号 & $\begin{array}{c}\text { 湖区 } \\
\left(\text { 面积 } / \mathrm{km}^{2}\right)\end{array}$ & 监测点 & 序号 & $\begin{array}{c}\text { 湖区 } \\
\left(\text { 面积 } / \mathrm{km}^{2}\right)\end{array}$ & 监测点 \\
\hline 1 & 梅梁湖 & 梅园 & 12 & 东太湖 & 东太湖 & 23 & 东部 & 西山 \\
\hline 2 & $(124.0)$ & 小湾里 & 13 & (172.4) & 庙港 & 24 & 沿岸区 & 胥口 \\
\hline 3 & & 闾江口 & 14 & & 戗港外 & 25 & $(268.0)$ & 漫山 \\
\hline 4 & & 拖山 & 15 & 湖心区 & 乌龟山 & 26 & & 胥湖 \\
\hline 5 & & 三号标 & 16 & $(972.9)$ & 焦山 & 27 & 南部 & 夹浦 \\
\hline 6 & 竺山湖 & 竺山湖 & 17 & & 平台山 & 28 & 沿岸区 & 新塘 \\
\hline 7 & $(68.3)$ & 龙头 & 18 & & 14 号标 & 29 & $(363.0)$ & 小梅口 \\
\hline 8 & 贡湖 & 沙墩港 & 19 & & 湖心南 & 30 & & 大钱 \\
\hline 9 & $(163.8)$ & 渔业村 & 20 & & 横山 & 31 & & 汤溇 \\
\hline 10 & & 大贡山 & 21 & 西部 & 大浦 & 32 & 五里湖 & 东五里湖 \\
\hline 11 & & 贡湖 & 22 & 沿岸区(199.8) & 淡东 & 33 & $(5.8)$ & 西五里湖 \\
\hline
\end{tabular}

\section{2 采样与检测方法}

水体总磷、溶解性总磷、正磷酸盐浓度的测定参照《水质 总磷的测定 钿酸铵分光光度法 (GB $11893-$ 1989 )》. 水样采样层面为水下 $0.5 \mathrm{~m}$, 按照《地表水环境质量标准 (GB 3838-2002)》的要求, 水样经静置沉 淀 30 分钟后取上清液测定总磷浓度. 具体做法是水样摇匀后, 倒人 $2 \mathrm{~L}$ 量筒静置沉淀 $30 \mathrm{~min}$ 后, 虹吸管插 人液面下 $5 \mathrm{~cm}$, 取上清液人样品瓶, 摇勺后取试样按 GB 11893-1989 要求消解后加人显色剂比色测定. 溶 解性总磷浓度用 $0.45 \mu \mathrm{m}$ 孔径的滤膜过滤后, 同样按 GB 11893-1989 方法消解后加人显色剂比色测定. 正 磷酸盐浓度则用过滤后水样不经消解直接显色测定. 采用《内陆水域浮游植物监测技术规程 (SL 7332016)》中镜检计数法检测水体蓝藻密度.

\section{3 数据处理与统计方法}

1.3.1 水质 各湖区监测点代表水域面积采用泰森多边形法确定, 以此为权重, 计算各湖区水质浓度; 太湖水 质浓度由各湖区水质按湖区面积加权计算确定. 如竺山湖水质浓度由竺山湖和龙头 2 个监测点水下 $0.5 \mathrm{~m}$ 水质浓度,分别乘以 2 个监测点的代表面积加和,除以竺山湖水域面积计算而得.

1.3.2 入湖污染负荷 各人湖河流进行污染负荷计算 ${ }^{[12]}$ 时, 以当月人湖河流巡测断面水量作为月人湖水量, 若人湖河流没有逐月水量巡测资料, 则选择其与相应巡测段内基点站的年水量分配比重作为权重进行计 算; 水质资料选取人湖河流相应断面逐月浓度. 各人湖河流历年来监测断面位置略有调整, 均采用实测水质 资料进行分析, 未进行修正 (区域或总体人湖污染负荷均以人湖水量为权重对人湖河流水质浓度进行空间 和时间上的累加,如果该巡测段 (站) 无人湖水量则其污染负荷量为零). 出人湖水量计算与分析按照地区划 分, 污染负荷量的统计按照太湖湖区来划分.

1.3.3 相关性分析 各项数据之间的相关性分析采用 SPSS Statistics 25 软件进行.

\section{2 结果与分析}

\section{1 太湖磷浓度分布状况}

太湖水中磷可以分为颗粒态磷和溶解态磷. 颗粒态磷主要分悬浮泥沙和生物体及其残体碎屑两类, 溶 解态磷主要为无机磷和溶解态的有机磷. 2010-2017 年, 太湖总磷年均浓度 $0.076 \mathrm{mg} / \mathrm{L}$, 总体呈上升趋势. 其中 2010-2014 年上下波动, 2014- 2017 年呈上升趋势, 且 2016 年为 8 年间最高值, 浓度达到 $0.097 \mathrm{mg} / \mathrm{L}$. 溶解性磷年均浓度 $0.026 \mathrm{mg} / \mathrm{L}$, 占总磷浓度的 $34.4 \%$, 波动趋势与总磷较为一致; 其中溶解性磷中的正磷酸 盐是被藻类和高等水生植被吸收利用的最主要形式, 正磷酸盐年均浓度 $0.013 \mathrm{mg} / \mathrm{L}$, 占总磷浓度的 $17.3 \%$, 总体上呈小幅上升趋势.

从各湖区 (图 2) 看, 总磷浓度较高的湖区有竺山湖、西部沿岸区和梅梁湖. 其中竺山湖总磷浓度最高, 
且波动明显; 其次为西部沿岸区, 总磷浓度居高不下; 而梅梁湖总磷浓度呈明显的增长趋势, 增长幅度较大. 总磷浓度最小的湖区为东部沿岸区, 其次为东太湖, 其中东太湖总磷浓度变化趋势总体上呈增长趋势, 尤其 是 2014 年后呈明显上升趋势, 2017 年总磷浓度较 2014 年增长 49\%,为各湖区中增长幅度最大的湖区.
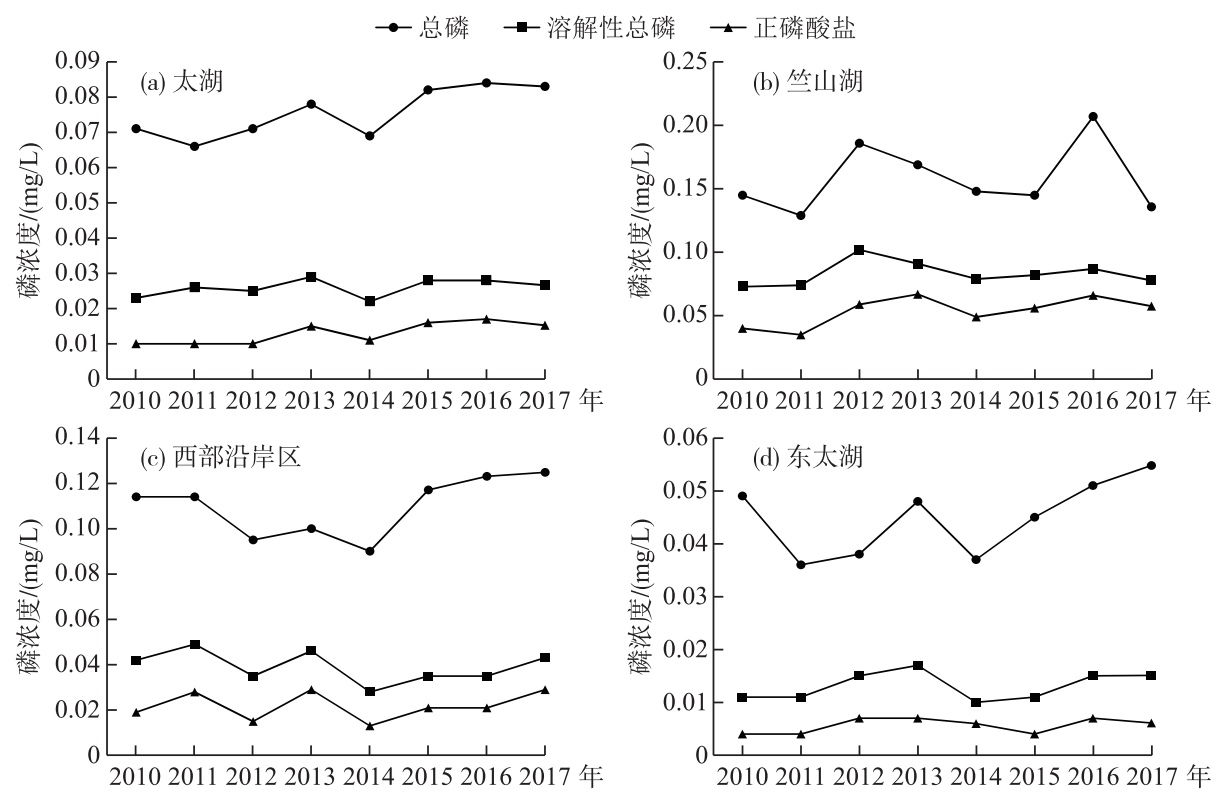

图 2 太湖及重点湖区磷浓度年均值变化

Fig. 2 Annual mean change of phosphorus concentration in Lake Taihu and key lake regions

\section{2 太湖蓝藻分布状况}

2010-2017 年, 太湖均为中度富营养状态, 全湖藻类密度、蓝藻密度和叶绿素 a 浓度总体上均呈上升趋 势,其中 2015 年较 2014 年略有降幅 (图 3). 其中藻类密度从 2010 年的 $1702 \times 10^{4}$ cells/L 增长到 2017 年的 $12227 \times 10^{4}$ cells $/ \mathrm{L}$, 增幅为 $618 \%$, 蓝藻密度从 2010 年的 $1394 \times 10^{4}$ cells $/ \mathrm{L}$ 增长到 2017 年的 $11766 \times 10^{4}$ cells $/ \mathrm{L}$, 增幅为 744\% , 叶绿素 a 浓度从 2010 年的 $19.4 \mathrm{mg} / \mathrm{m}^{3}$ 增加到 2017 年的 $45.5 \mathrm{mg} / \mathrm{m}^{3}$, 增幅为 $134.5 \%$. 其中蓝 藻密度占藻类的比重总体上呈上升趋势, 从 2010 年的 $82 \%$ 增加到 2017 年的 $96 \%$.

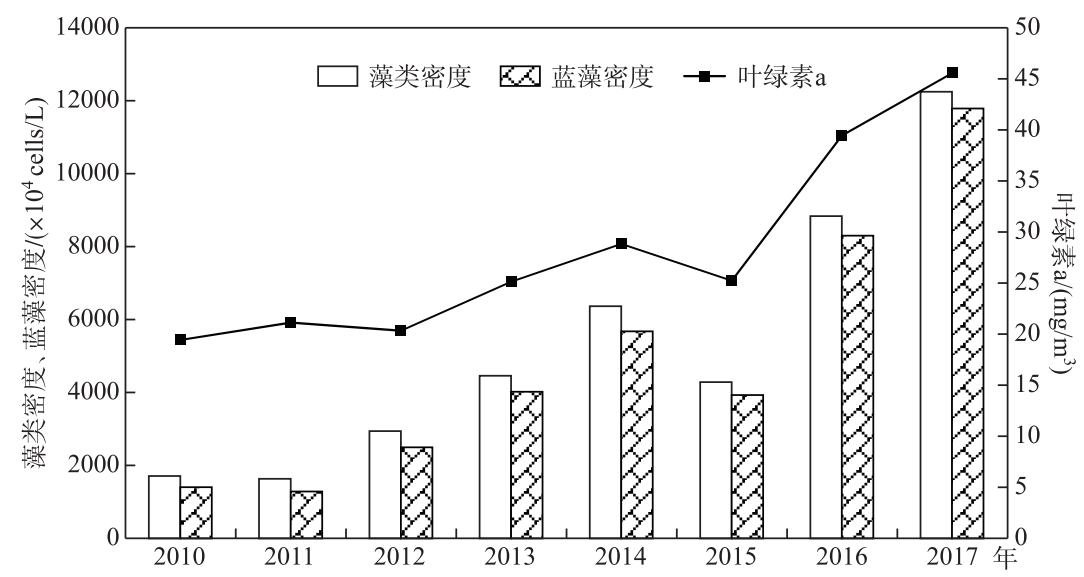

图 $32010-2017$ 年太湖蓝藻状况

Fig. 3 Conditions of cyanobacteria in Lake Taihu from 2010 to 2017 
从太湖各湖区蓝藻密度来看, 梅梁湖和西部沿岸区蓝藻数量最高 (图 4), 梅梁湖 2017 年蓝藻密度达到 $24662 \times 10^{4}$ cells $/ \mathrm{L}$, 为太湖的 2.1 倍, 西部沿岸区蓝藻密度达到 $21541 \times 10^{4}$ cells $/ \mathrm{L}$. 其中东太湖曾为蓝藻数量 最少的湖区, 但近年来东太湖蓝藻数量上升趋势明显, 从 2010 年的 $446 \times 10^{4}$ cells/L 增加到 2017 年的 $2651 \times$ $10^{4}$ cells/L, 增幅近 5 倍.

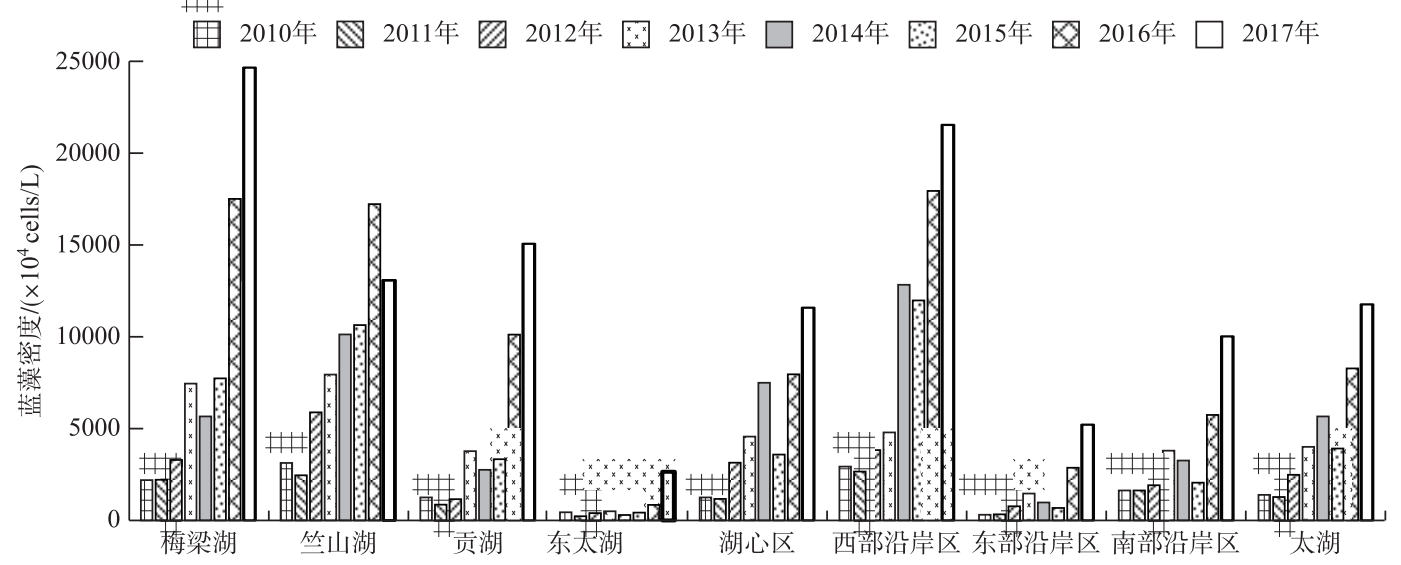

图 4 2010－2017 年太湖各湖区蓝藻密度

Fig.4 Cyanobacteria density in each lake region of Lake Taihu from 2010 to 2017

\section{3 环太湖入湖河流总磷污染负荷}

2010－2017 年, 环太湖人湖河流总磷浓度总体呈下降趋势, 2017 年总磷浓度较 2010 年下降了 $22.3 \%$ (图 5 ), 与同时段人湖河流水质总氮浓度下降 $28.5 \%$ 相比, 人湖总磷浓度降幅小于人湖总氮浓度的降幅. 人 湖径流污染负荷是太湖磷最主要的外源, 根据人湖河道水质和水文巡测流量数据, 计算环太湖人湖河流总 磷总人湖量. 2010-2017 年环太湖人湖河流总磷总人湖量年均值为 0.22 万 $\mathrm{t}$, 总体呈波动变化趋势, 2010一 2013 年呈下降趋势, 2014- 2016 年呈上升趋势, 2017 年有所下降,其中 2010 年总磷总人湖量为 0.28 万 t, 2016 年为 0.26 万 $\mathrm{t}, 2017$ 年为 0.20 万 $\mathrm{t}$.

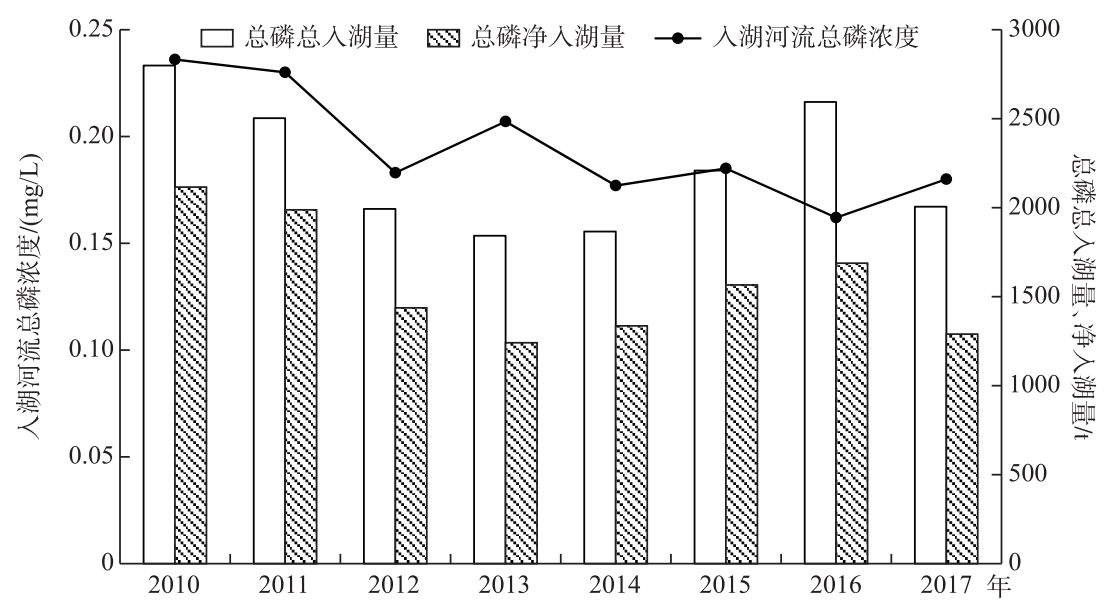

图 5 环太湖人湖河流总磷污染负荷

Fig.5 Total phosphorus pollution load of rivers into the Lake Taihu 


\section{3 讨论}

太湖湖体的磷营养盐来源包括外源和内源. 外源形式较多, 其中人湖河道径流输人是外源负荷的最大 组成部分; 内源主要来源于底泥的释放、死亡的生物体分解以及围网养殖等 ${ }^{[14]}$. 其中水生植被是影响底泥 释放的主要因素,对磷的释放有至关重要的影响,因此本文重点分析水生植被.

磷由外源进入湖泊后, 一部分随着水流流出湖外, 另一部分滞留在湖水中. 湖水中的可溶性磷 (包括部 分无机磷和少部分有机磷) 主要直接被藻类和植物吸收; 颗粒态磷可沉积进人底泥, 部分溶解态磷可反应生 成沉淀物进入底泥 ${ }^{[15]}$. 底泥中的磷相当部分与湖底的固化沉积物结合, 一般不再释放到水中参与磷循环, 但在风浪等物理扰动作用下可再悬浮进人水体, 也可在 $\mathrm{pH}$ 值、氧化还原电位等化学因素和微生物等作用 下, 转化为可溶性磷释放进人水体. 特别当蓝藻水华发生时, 为维持藻类生长对磷的需求, 藻体大量吸收水 体中的正磷酸盐, 并通过影响水体 $\mathrm{pH}$ 值、溶解氧浓度和分泌磷酸酶等方式, 加速底泥中磷的释放和水体有 机磷分解, 加快湖体磷循环速度.

根据太湖磷营养盐的来源及循环机理, 本文重点讨论人湖污染负荷、水生植被和蓝藻 3 方面对太湖总 磷浓度的影响.

\section{1 入湖污染负荷对太湖总磷浓度的影响}

太湖主要人湖河流污染负荷占人湖总污染负荷的 70\% 80\%, 控制人湖河流污染负荷是太湖治理的关 键因素 ${ }^{[16]}$. 目前, 太湖总磷污染负荷仍较大, 呈波动趋势, 2010-2017 年仅环太湖河流径流输人的磷年平均 达 0.22 万 $\mathrm{t}$, 人湖河流总磷平均浓度为太湖总磷平均浓度的 2.1 倍, 超出太湖自净能力 ${ }^{[17-18]}$.

西部沿岸区对应河流人湖水量占环太湖河流人湖水量比重较大, 分析西部沿岸区对应人湖河流总磷负 荷及湖区总磷浓度之间变化情况具有重要意义.

根据图 6 分析可知, 2010-2017 年间,西部沿岸区对应人湖河流总磷浓度以 2011 年最高,之后总体呈 下降趋势. 但受人湖水量较常年偏多的影响, 特别是 2015 和 2016 年大洪水期间, 年度总磷总人湖量和总磷 净人湖量连续增加, 使得进人太湖的总磷负荷呈上升趋势. 根据相关性分析, 湖区总磷浓度与人湖河流总磷 浓度和人湖河流总磷负荷三者之间没有同步变化趋势. 其中湖区总磷浓度与人湖河流总磷浓度之间无明显 的相关性, 因此人湖河流总磷浓度对湖区总磷浓度没有直接的影响; 湖区总磷浓度与人湖河流总磷负荷两 者之间有一定的同步关系, 因此人湖总磷负荷直接影响对应湖区的总磷浓度. 因此, 湖区总磷浓度影响因素 是由人湖河流总磷浓度和人湖河流水量两者共同决定的, 即人湖总磷负荷, 尤其 2016 年大洪水期间, 人湖 总磷负荷量增大与总磷浓度反弹有较大的关系.

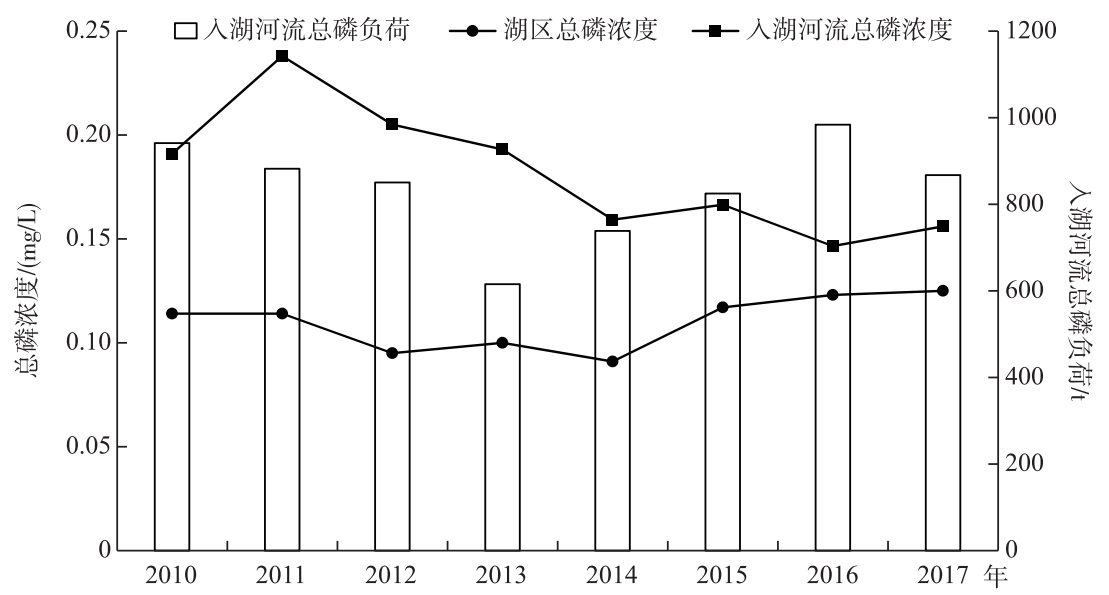

图 6 2010-2017 年太湖西部沿岸区总磷浓度变化趋势

Fig. 6 Change trend of total phosphorus concentration in west region of Lake Taihu from 2010 to 2017 
与湖体中氮循环不同, 磷循环转化呈气态逸出的量占比非常小, 同时磷易与金属离子结合形成沉淀物, 因此磷更易沉积于湖底, 使得太湖底泥总磷含量维持在较高水平. 同时其他途径出湖的总磷量比重较 小 ${ }^{[19]}$, 因此本文重点分析地表径流人太湖的总磷净人湖量, 通过分析 2010-2017 年太湖总磷净人湖量累积 量与太湖总磷浓度的关系 (图 7) 可知, 逐年总磷净人湖量累积值与太湖总磷浓度呈二次线性相关, 相关系数 为 0.8315 . 因此, 太湖总磷浓度与逐年总磷净人湖量累计值有较大的关系.

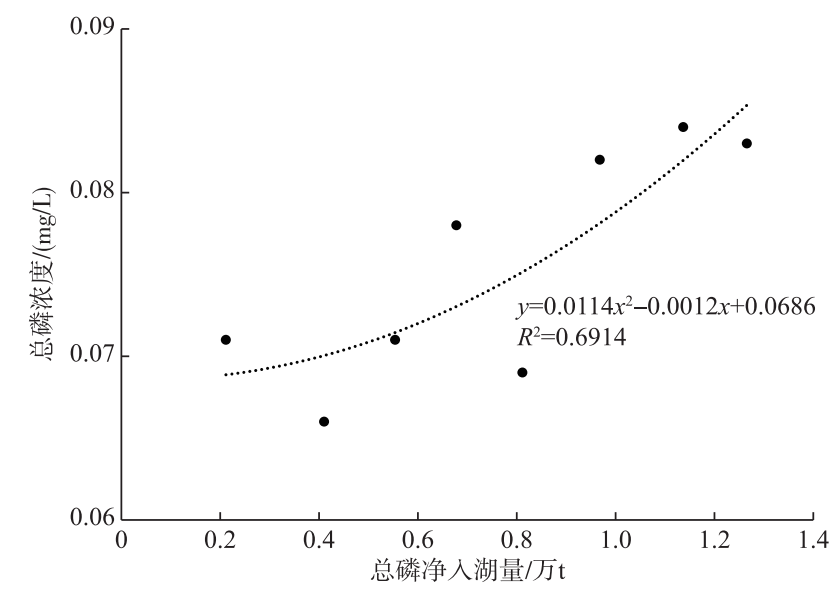

图 $72010-2017$ 年太湖总磷净人湖量累积量与总磷浓度的关系

Fig.7 Relationship between total phosphorus concentration and total phosphorus accumulation in Lake Taihu from 2010 to 2017

综上所述, 人湖总磷负荷变化是太湖总磷浓度变化的直接因素, 由于磷相较于氮更易滞留于湖体, 使得 太湖湖体的总磷浓度维持在较高水平. 因此, 磷入湖量大是湖水总磷浓度居高不下的基础因素.

\section{2 水生植被对太湖总磷浓度的影响}

3.2.1 太湖水生植被状况 太湖水生植被主要包括沉水植被和挺水植被, 根据 2013-2017 年太湖水生高等 植被遥感图结果显示, 与 2014 年较相比, 2015 年 5 月水生植被覆盖面积由 $272.33 \mathrm{~km}^{2}$ 降至 $55.96 \mathrm{~km}^{2}$, 减少 了 $79.5 \%$. 其中主要是沉水植被面积大幅减少, 由 $244.31 \mathrm{~km}^{2}$ 下降至 $27.65 \mathrm{~km}^{2}$, 减少了 $88.7 \%$; 挺水植被面 积变化很小. 沉水植被主要分布在东太湖、东部沿岸区两个湖区, 挺水植被主要分布在太湖大堤沿岸内侧 (图 8).

3.2.2 东太湖水生植被大量减少对总磷浓度的影响分析 本文以东太湖为例, 重点分析水生植被对太湖总磷 浓度的影响. 东太湖曾经为典型草型湖区,近年来由于水生植被大量减少, 水生态状况发生了较大变化. 不 同水生态系统中营养盐赋存形态不同, 藻型生态系统中磷营养盐浓度高于草型生态系统 ${ }^{[20]}$. 东太湖沉水植 被覆盖面积从 2015 年开始大幅减少,与 2014 年相比, 2015 年 5 月沉水植被覆盖面积由 $65.53 \mathrm{~km}^{2}$ 降至 24.81 $\mathrm{km}^{2}$, 减少 $62.1 \%, 2016$ 年持续减少, 2017 年东太湖沉水植被虽有所恢复,但较 2015 年同期水平还有较大差 距. 根据东太湖 5 月水生植被的变化与同期东太湖总磷浓度分析可知 (图 9),2013-2017 年 5 月东太湖水 生植被面积和总磷浓度呈明显的反向变化. 因此, 由于近年来水生植被的大量减少, 曾经为草型生态系统的 东太湖正在呈现向藻型生态系统转化的趋势.

水生植被可吸收湖泊沉积物中的营养盐, 并抑制底泥再悬浮从而降低内源性营养盐的释放. 太湖是一 个典型的大型浅水湖泊, 水土界面不断受到风浪扰动导致沉积物大量悬浮, 水土界面不断受到破坏, 氧化还 原环境在这种动力扰动下处于不断转换中. 风浪扰动能够促进底泥营养盐的大量释放 ${ }^{[21]}$, 底泥释放能够促 进水体总氮、总磷和活性磷浓度的显著升高 ${ }^{[22]}$. 大型水生植被的退化, 使得水体富营养化程度加剧, 造成恶 性循环, 总磷浓度不断上升.

综上,2015 年由于东太湖水生植被面积大幅减小,一方面减少了总磷的吸收量, 另一方面有利于风浪对 

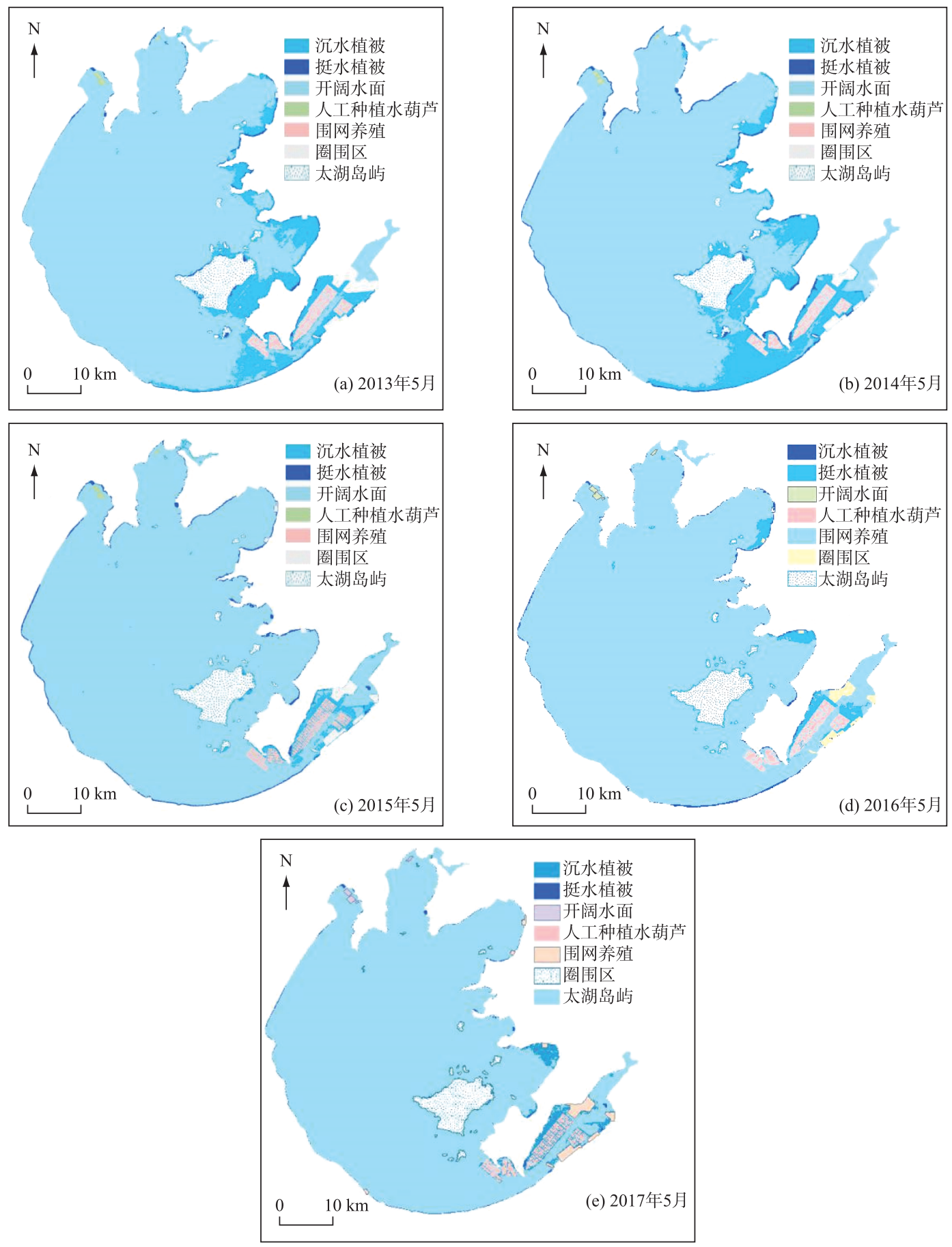

图 8 2013-2017 年 5 月太湖水生植被分布比较

Fig.8 Comparison of aquatic vegetation distribution of Lake Taihu in May of 2013-2017

底泥的再悬浮而促进底泥总磷的释放, 从而使得东太湖水质浑浊. 因此, 东太湖水生植被大量减少, 有利于 底泥中总磷的释放, 使得水体富营养化程度加剧, 是近年来东太湖总磷浓度持续上升的原因之一. 


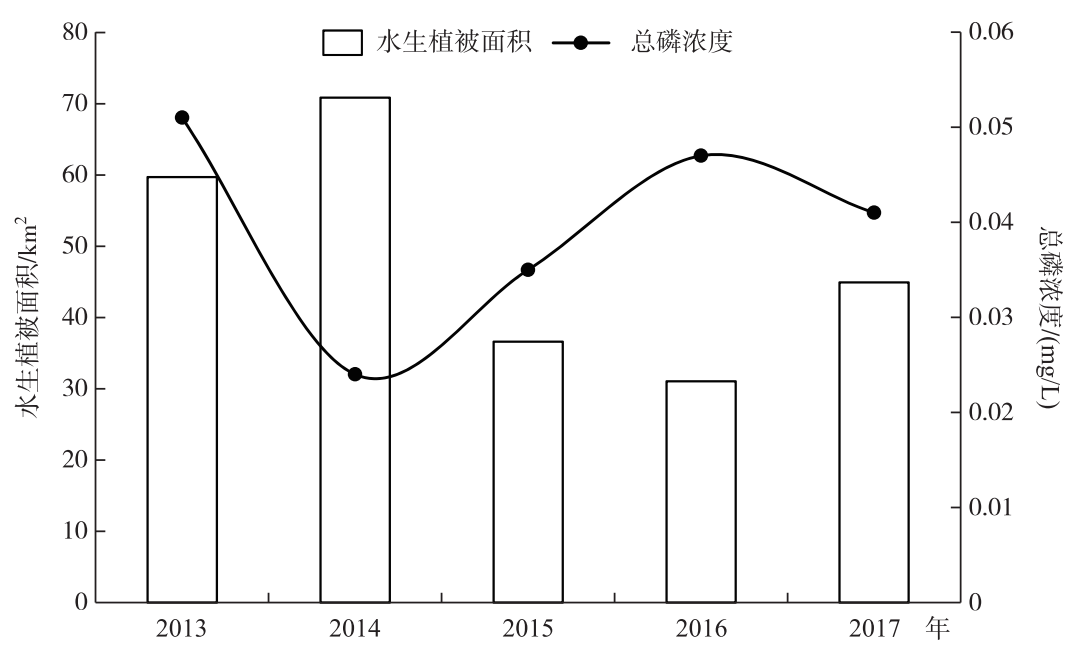

图 9 2013-2017 年东太湖 5 月水生植被面积和总磷浓度变化情况

Fig.9 Changes of aquatic vegetation area and total phosphorus concentration in East Lake Taihu in May of 2013-2017

\section{3 太湖蓝藻对总磷浓度的影响}

太湖水体磷营养盐浓度影响着蓝藻水华暴发的强度, 蓝藻水华对磷营养盐浓度的变化也存在反馈机制. 太湖蓝藻的快速生长导致其从底泥中原取大量的磷, 从而增加底泥中磷的释放和有机磷的转化, 加快湖体 磷循环, 增加水体总磷浓度. 蓝藻水华发生时, 由于大量利用 $\mathrm{CO}_{2}$ 进行光合作用, 水体 $\mathrm{pH}$ 值上升, 太湖蓝藻 生长季节 $\mathrm{pH}$ 值多大于 8.5 , 甚至超过 9.0 , 偏碱性环境更有利于底泥磷的释放. 蓝藻生长大量消耗水中无机 磷, 通过分泌碱性磷酸酶可加快死亡藻体分解的有机磷转化为可利用的无机磷.

太湖总磷以颗粒态为主, 2010-2017 年平均比 例占 $65.6 \%$,颗粒态磷除了外源输人外, 主要来源于 底泥再悬浮和藻体. 根据统计, 太湖各测点颗粒态 磷浓度与叶绿素 $\mathrm{a}$ 浓度的相关系数为 0.7413 , 存在 显著的正相关关系 (图 10). 目前采样层面为水下 $0.5 \mathrm{~m}$, 太湖发生蓝藻水华时, 水样中有大量蓝藻, 当 水样静置 $30 \mathrm{~min}$ 后, 蓝藻向表层聚集,但用于总磷 测定的上清液中仍有较多蓝藻, 藻体中的磷一同被 消解检测. 近年来太湖蓝藻数量呈上升趋势, 受其 影响, 总磷浓度监测值也有上升. 蓝藻水华加快湖 体磷循环, 藻类数量增加也是近两年太湖总磷浓度 上升的影响因素之一.

\section{4 结论}

本研究显示, 近年来太湖水体总磷浓度持续增

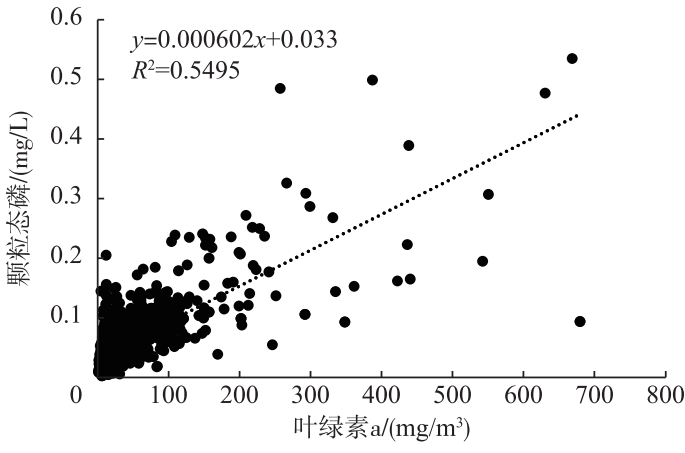

图 10 太湖各监测点颗粒态磷浓度与 叶绿素 a 浓度的相关关系

Fig.10 Relationship between chlorophyll-a concentration and particle phosphorus concentration at each monitoring site in Lake Taihu 长的初步原因为: 1) 磷循环不同于氮循环, 呈气态 逸出量占比非常小, 入湖河流总磷平均浓度高于太湖水体平均浓度, 超出水体自净能力, 且逐年总磷净入湖 量持续累积, 太湖总磷浓度维持较高水平, 磷人湖污染负荷量大是湖水总磷浓度居高不下的根本原因, 尤其 2016 年大洪水期间, 人湖总磷负荷量增大与总磷浓度反弹有较大的关系. 2) 水生植被可吸收湖泊沉积物中 的营养盐, 并抑制底泥再悬浮从而降低内源性营养盐的释放. 东太湖水生植被大量减少, 一方面减少了对 氮、磷的吸收, 另一方面增加了风浪对底泥的扰动, 有利于底泥的再悬浮, 造成总磷的释放. 3) 蓝藻水华加快 
湖体磷循环, 藻类数量增加也是近两年太湖总磷浓度上升的影响因素之一.

分析近年来太湖水体磷浓度总体上升的影响因素, 有助于为太湖的污染治理相关措施的实施提供有价 值的参考.

致谢:衷心感谢水利部太湖流域管理局朱威副局长在论文修改中无私的帮助和指导! 衷心感谢太湖流域水 资源保护局翟淑华处长的支持!

\section{5 参考文献}

[ 1 ] Dai XL, Qian PQ, Ye L et al. Evolution trend of nitrogen and phosphorus concentration in Lake Taihu( 1985-2015). J Lake Sci, 2016, 28(5): 935-943. DOI: 10.18307/2016.0502. [ 戴秀丽, 钱佩琪, 叶凉等. 太湖水体氮、磷浓度演变 趋势 (1985-2015 年). 湖泊科学, 2016, 28(5): 935-943.]

[ 2 ] Wu P, Qin BQ, Yu G et al. Effects of economic development on wastewater discharge and influent total phosphorus load in the upstream of Lake Taihu Basin. J Lake Sci, 2015, 27(6) : 1107-1114. DOI: 10.18307/2015.0616. [吴攀, 秦伯强, 于革等. 太湖上游流域经济发展对废水排放及人湖总磷的影响. 湖泊科学, 2015, 27(6) : 1107-1114.]

[ 3 ] Zhu W, Tan YQ, Wang RC et al. The trend of water quality variation and analysis in typical area of Lake Taihu, 20102017. J Lake Sci , 2018, 30(2) : 296-305. DOI: 10.18307/2018.0202. [朱伟, 谈永琴, 王若辰等. 太湖典型区20102017 年间水质变化趋势及异常分析. 湖泊科学, 2018, 30(2) : 296-305.]

[ 4 ] Zhu GW, Qin BQ, Zhang YL et al. Varition and driving factors of nutrients and chlorophyll-a concentrations in northern region of Lake Taihu, China, 2005-2017. J Lake Sci, 2018, 30(2) : 279-295. [朱广伟, 秦伯强, 张运林等. 20052017 年北部太湖水体叶绿素 a 和营养盐变化及影响因素. 湖泊科学, 2018, 30(2): 279-295.]

[ 5 ] Yang Y, Liu QG, Hu ZJ et al. Distribution and pollution assessment of carbon, nitrogen and phosphorus in sediments in Taihu Basin. Journal of Environmental Science, 2014, 34(12): 3057-3064. [杨洋, 刘其根, 胡忠军等. 太湖流域沉积 物碳氮磷分布与污染评价. 环境科学学报, 2014, 34(12) : 3057-3064.]

[6 ] Wu YL, Xu H, Yang GJ et al. Research progress of nitrogen pollution in Lake Taihu. J Lake Sci, 2014, 26(1): 19-28. DOI : 10.18307/2014.0103. [ 吴雅丽, 许海, 杨桂军等. 太湖水体氮素污染状况研究进展. 湖泊科学, 2014, 26 (1) : 19-28.]

[ 7 ] Lin ZX. Analysis of water environmental change in Taihu watershed. J Lake Sci, 2002, 14(2) : 111-116. DOI: 10.18307/ 2002.0203. [ 林泽新. 太湖流域水环境变化及缘由分析. 湖泊科学, 2002, 14(2): 111-116.]

[ 8 ] Xu HP, Yang GJ, Zhou J et al. Effect of nitrogen and phosphorus concentration on colony growth of Microcystis flos-aquae in Lake Taihu. J Lake Sci, 2014, 26(2) : 213-220. DOI: 10.18307/2014.0207. [许慧萍, 杨桂军, 周健等. 氮、磷浓度 对太湖水华微囊藻 (Microcystis flos-aquae) 群体生长的影响. 湖泊科学, 2014, 26(2) : 213-220.]

[ 9 ] Chen C, Zhong JC, Shao SG et al. On the potential release rates of nutrient from internal sources: A comparative study of typical dredged and un-dredged areas, northwestern Lake Taihu. J Lake Sci, 2014, 26(6) : 829-836. DOI: 10.18307/ 2014.0603. [ 陈超, 钟继承, 邵世光等. 太湖西北部典型疏浚/对照湖区内源性营养盐释放潜力对比. 湖泊科学, $2014,26(6)$ : 829-836. ]

[10] Zhai SH, Han T, Chen F. Self-purification capacity of nitrogen and phosphorus of Lake Taihu on the basis of mass balance. J Lake Sci, 2014, 26(2) : 185-190. DOI: 10.18307/2014.0203. [ 翟淑华, 韩涛, 陈方. 基于质量平衡的太湖氮、磷自 净能力计算. 湖泊科学, 2014, 26(2): 185-190.]

[11] Bai XX, Hu WP. Effect of water depth on concentration of TN, TP and Chla in Taihu Lake, China. Advances in Water Science, 2006, 17 (5) : 727-732. [ 白晓华, 胡维平. 太湖水深变化对氮磷浓度和叶绿素 a 浓度的影响. 水科学进展, 2006, 17(5): 727-732. ]

[12] Tao YY, Geng JJ, Wang HJ et al. Spatio-tempo variations of dissolved phosphorus concentrations in Lake Taihu. Environmental Monitoring in China, 2013, 29 (5) : 84-90. [ 陶玉炎, 耿金菊, 王红军等. 太湖水体溶解态磷的时空变化特征. 中国环境监测, 2013, 29(5):84-90.]

[13] Xie EL, Xu F, Xiang L et al. The effect of pollution load on water quality of Lake Taihu and its trend analysis. Journal of Hohai University: Natural Sciences, 2017, 45(5) : 391-397. [谢艾玲, 徐枫, 向龙等. 环太湖主要人湖河流污染负荷 量对太湖水质的影响及趋势分析. 河海大学学报: 自然科学版, 2017, 45(5): 391-397.]

[14] Qin BQ, Zhu GW, Zhang L et al. Release pattern and estimation method of endogenous nutrient salt from sediments of 
large shallow lakes—Lake Taihu as an example. Science China: Series D: Earth Science, 2005, (S2): 33-44. [ 秦伯强, 朱广伟, 张路等. 大型浅水湖泊沉积物内源营养盐释放模式及其估算方法一以太湖为例. 中国科学: D 辑: 地 球科学, 2005, (S2) : 33-44.]

[15] Zuo MM. Conversion and circulation of phosphorus in water. In: Chinese Society of Environmental Science ed. Collection of excellent papers from the 2006 annual academic conference of the Chinese society of environmental science (middle volume), 2006: 4. [ 左梅梅. 水体中磷的转化与循环. 中国环境科学学会 2006 年学术年会优秀论文集 (中卷), 2006: 4. ]

[16] Overall plan for comprehensive treatment of water environment in Taihu Basin (revised in 2013). [太湖流域水环境综合 治理总体方案(2013 年修编), 发改地区[2013]2684 号.]

[17] Hang T, Zhai SH, Hu WP et al. Experiment and model simulation of phosphorus self-purification capacity. Environmental Science, 2013, 34(10) : 3862-3871. [韩涛, 翟淑华, 胡维平等. 太湖氮、磷自净能力的实验与模型模拟. 环境科学, 2013, 34(10): 3862-3871.]

[18] Wang XM, Zhai SH, Zhang HJ et al. Analysis of appropriate water exchange period of Lake Taihu based on water quality improvement targe. J Lake Sci, 2017, 29(1) : 9-21. DOI: 10.18307/2017.0102. [王冼民, 翟淑华, 张红举等. 基于水 质改善目标的太湖适宜换水周期分析. 湖泊科学, 2017, 29(1) : 9-21.]

[19] Yu H, Zhang LL, Yang SW et al. Atmospheric wet deposition characteristics and contribution rate of nitrogen and phosphorus nutrient salt from Lake Taihu. Research of Environmental Sciences, 2011, 24(11): 1210-1219. [余辉, 张璐璐, 燕姝雯等. 太湖氮磷营养盐大气湿沉降特征及人湖贡献率. 环境科学研究, 2011, 24(11) : 1210-1219.]

[20] Yang LY, Yang XY, Ren LM et al. Mechanism and control strategy of cyanobacterial bloom in Lake Taihu. J Lake Sci, 2019, 31(1) : 18-27. DOI: 10.18307/2019.0102. [杨柳燕, 杨欣妍, 任丽曼等. 太湖蓝藻水华爆发机制与控制对 策. 湖泊科学, 2019, 31(1): 18-27.]

[21] Zhu GW, Qin BQ, Gao G. The vertical distribution characteristics of nutrient salts in Lake Taihu under the disturbance of wind and waves. Advances in Water Science, 2004, (6) : 775-780. [ 朱广伟, 秦伯强, 高光. 强弱风浪扰动下太湖的营 养盐垂向分布特征. 水科学进展, 2004, (6) : 775-780.]

[22] Wang XD, Qin BQ, Liu LZ et al. Effects of sediment suspension on nutrient release and bloom growth. Resources and Environment in the Yangtze Basin, 2011, 20(12): 1481-1487. [王小冬, 秦伯强, 刘丽贞等. 底泥悬浮对营养盐释放和水 华生长影响的模拟. 长江流域资源与环境, 2011, 20(12): 1481-1487.] 